\title{
Toxicological Evaluation of Kenaf Seed Supercritical Carbon Dioxide-Oil in Male Sprague Dawley Rats
}

\author{
Siti Aisyah Abd Ghafar ${ }^{*}$, Latifah Saiful Yazan², Sharida Fakhurazi ${ }^{2,3}$ and Maznah Ismail2,3 \\ ${ }^{1}$ Department of Oral Biology and Basic Sciences, Faculty of Dentistry, Universiti Sains Islam Malaysia, 55100, Kuala \\ Lumpur, Malaysia \\ ${ }^{2}$ Faculty of Medicine and Health Sciences, Universiti Putra Malaysia, 43400 UPM Serdang, Selangor Darul Ehsan,
} Malaysia

${ }^{3}$ Nutraceutical and Nutrigenomic Programme, Laboratory of Molecular Biomedicine, Institute of Bioscience, Universiti Putra Malaysia, 43400 UPM Serdang, Selangor Darul Ehsan, Malaysia

\begin{abstract}
Kenaf seed supercritical carbon dioxide oil (KSO-SFE) is known for its numerous health benefits such as high antioxidant activity, lower plasma cholesterol level, chemopreventive to cervical and colon cancer. As there has been no report of toxicological evaluation, present study was conducted to assess the toxicity effects of $\mathrm{KSO}-\mathrm{SFE}$ at $500,1000,1500 \mathrm{mg} / \mathrm{kg}$ body weight/day on male Sprague Dawley rats for 90 days. Parameters measured were body and organs weight, hematology, serum biochemistry, and histopathology of liver and kidneys. Induction with KSO-SFE showed lower creatinine level at all doses when compared with control group. Whereas lower plasma cholesterol level has been observed at 1000 and $1500 \mathrm{mg} / \mathrm{kg}$ bw/day, respectively. These slight changes were considered no toxicological significance. No mortality or treatment-related adverse effects in any of the parameters measured throughout the administration period even at the highest dose (1500 $\mathrm{mg} / \mathrm{kg} \mathrm{bw}$ ). Based on these results, the no-adverse-effect level (NOAEL) for KSO-SFE under the condition of this study corresponds to the highest dose ( $1500 \mathrm{mg} / \mathrm{kg} \mathrm{bw} /$ day).
\end{abstract}

Keywords: kenaf seed oil; supercritical fluid extraction; toxicology; Sprague Dawley

\section{INTRODUCTION}

Kenaf (Hibiscus cannabinus), from Malvaceae family, is a tall herbaceous yearly woody tropical plant. It has been introduced in Malaysia as a fibre crop to replace tobacco. Usually, kenaf seeds were disposed as unused material during collecting or managing of kenaf plantation. However, with the encouragement of Malaysian government, extensive research has been done on kenaf seeds. Kenaf seeds yield a considerable amount of vegetable oil (15-20\%) that is safe for individual consumption (Giwa Ibrahim et al., 2019). Kenaf seed oil (from hexane extraction) encompasses alphalinolenic acid (ALA), phytosterol and vitamin $\mathrm{E}$ that possess anticancer, antioxidant and lipid lowering properties (Mohamed et. al., 1995; Nyam et. al., 2009; Chew et al.,
2019). However, products that are acquired (especially oil) from organic solvents are continuously questioned for its safe intake owing to the imperfect solvent eradication. Therefore, supercritical fluid carbon dioxide extraction proposes a safer way of extraction.

Supercritical fluid extraction (SFE) offers an additional way of extraction method whereby supercritical fluids, as a substitute to organic solvents, are employed as an extraction medium. The most common supercritical solvents are carbon dioxide $\left(\mathrm{CO}_{2}\right) \cdot \mathrm{CO}_{2}$ is cheap, environmental-friendly and generally recognized as safe by U.S Food and Drug Administration (FDA) (Khaw et al., 2017). The advantage of using $\mathrm{CO}_{2}$ is its gaseous at room temperature and pressure, which makes extracts retrieval (such as oil) very 
straightforward and offers cleaner end products (Li et al., 2019). Based on literature, kenaf seed oil that extracted using SFE (KSO-SFE) gave higher amount of tocopherol and sterol when compared with hexane extraction (Chan and Ismail., 2009). KSO-SFE reduces aberrant crypt foci count (putative precursor in colon cancer) in azoxymethane induced rats, inhibits proliferation of colon cancer (HT29) and ovarian cancer cells (CaVo3) (Ghafar et al., 2012; Ghafar et al., 2013; Yazan et al., 2011). KSO-SFE has been proven to possess a lot of health benefits. Therefore a 90 days subchronic toxicity study of KSO-SFE in male Sprague Dawley rats was performed preclinically as supportive evidence on the benefits of KSO-SFE.

\section{MATERIALS AND METHOD}

\section{A. Preparation of KSO-SFE}

Kenaf seed (Figure 1) was acquired from the Malaysia Kenaf Tobacco Board, Pasir Putih, Kelantan. Kenaf seed was cleansed and desiccated at stable temperature $\left(50^{\circ} \mathrm{C}\right)$ overnight in the oven (FD 115, Fisher Scientific). The absolute humidity level of dried seed was less than $5 \%$. Kenaf seed oil was concocted using supercritical carbon dioxide fluid extractor (Thar $1000 \mathrm{~F}$, USA) at 600 bars, $40^{\circ} \mathrm{C}$. The detailed procedure has been previously reported in literature (Chan \& Ismail, 2009; Mariod et al., 2011; Ghafar et al., 2012). In brief, 100 grams of seed were milled using a stainless-steel mixer (Waring Commercial, USA) for one minute and positioned into a 1-litre extraction container. After the extraction container was securely sealed, the preferred temperature $\left(40^{\circ} \mathrm{C}\right)$ and pressure (600 bars) were then established. The flow rate of carbon dioxide was established at $25 \mathrm{~g} / \mathrm{min}$ and controlled by automated back pressure controller. The extraction begun following the anticipated temperature and pressure were achieved. The entire extraction procedure continued for two hours and thirty minutes. After the extraction was accomplished, the extraction container was depressurized and the oil was collected. The extracted oil was assembled and stored at $20^{\circ} \mathrm{C}$ until further used.

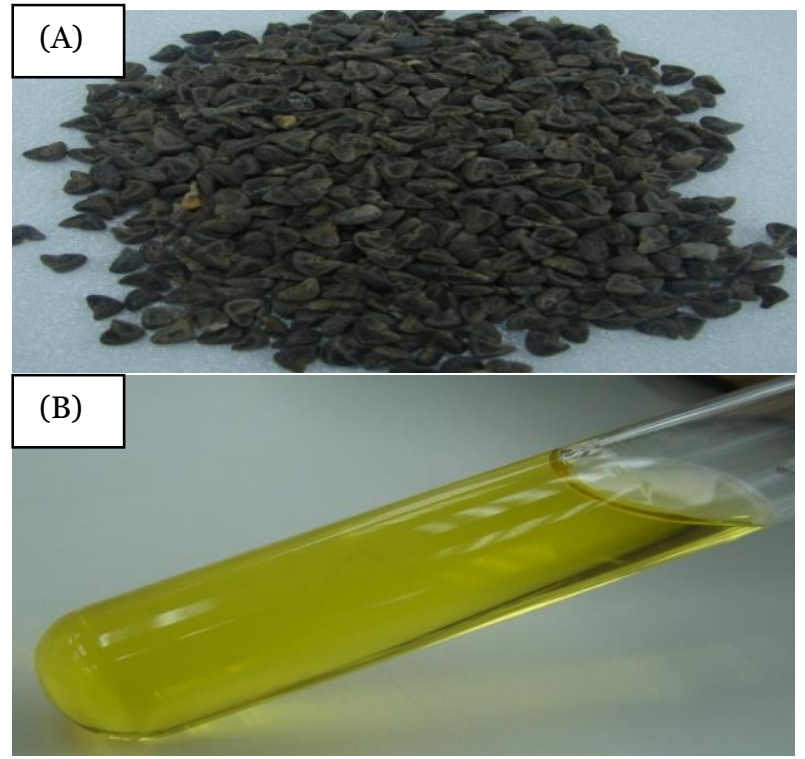

Figure 1. (A) Kenaf seed and (B) Kenaf seed oil extracted from supercritical fluid extraction (SFE)

\section{B. Experimental Animals}

Ethics endorsement for animal practice in this study was attained from the Animal Care and Use Committee (ACUC), Faculty of Medicine \& Health Sciences, Universiti Putra Malaysia (ACUC no: UPM/FPSK/PADS/BRUUH/oo256). Twenty-four male Sprague Dawley rats (at 4 weeks of age) weighed between 90 to $150 \mathrm{~g}$ were purchased from the Faculty of Veterinary Medicine, Universiti Putra Malaysia. They were maintained in a well-ventilated area at the animal house at room temperature, $29-32^{\circ} \mathrm{C}, 70-80 \%$ moisture with a 12 hours light/dark cycle. A total of 3 animals were sheltered in every cage and nourished with a basal diet for 13 weeks. Water and diet were given ad libitum. The animals were cared for as specified by the guidelines of the Animal Care and Use Committee (ACUC) Faculty of Medicine \& Health Sciences Universiti Putra Malaysia.

\section{Experimental Design}

In this study, 90 days of repeated dose oral toxicity evaluation was carried out on KSO-SFE. This study was based on Organization for Economic Co-operation and Development (OECD) test guideline 408 (OECD, 2018). They were divided into 4 groups as: negative control group (group 1), fed with 500, 1000 and $1500 \mathrm{mg} / \mathrm{kg}$ body weight KSO-SFE (group 2-4). Groups 2 to 4 were treated with KSOSFE through gavage every day in the morning for 90 days. Body weight was recorded weekly. At the end of 
administration period, the rats were let to be abstained overnight and blood was gathered via cardiac perforation. The liver, kidneys, heart, spleen, brain, lungs were harvested, washed with $0.9 \%$ saline and fixed in RCL2® solvent (Plaisir, France) for histopathological experiment (Masir et al., 2012).

\section{Hematological Assays}

Whole blood was examined with KX-21 haematology analyzer (Kobe, Japan). White blood cell (WBC), red blood cell (RBC), haemoglobin (HGB), hematocrit (HCT), mean corpuscular volume (MCV), mean corpuscular haemoglobin $(\mathrm{MCH})$, mean corpuscular haemoglobin concentration (MCHC), platelet (PLT), lymphocyte (LYM), red cell distribution width (RDW), platelet distribution width (PDW), mean platelet volume (MPV) and platelet larger cell ratio (P-LCR) amounts were measured.

\section{E. Biochemical Assays}

Blood was collected in EDTA tubes and centrifuged at 3000 $\mathrm{g}$ for 10 minutes to split the plasma. The plasma was subsequently explored with Vitalab Selectra-XL (Dieren, Netherland) for gamma-glutamyl transpeptidase (GGT), alanine transaminase (ALT), glucose, urea, creatinine, total cholesterol, high density lipoprotein (HDL), low density lipoprotein (LDL) and triglyceride (TG).

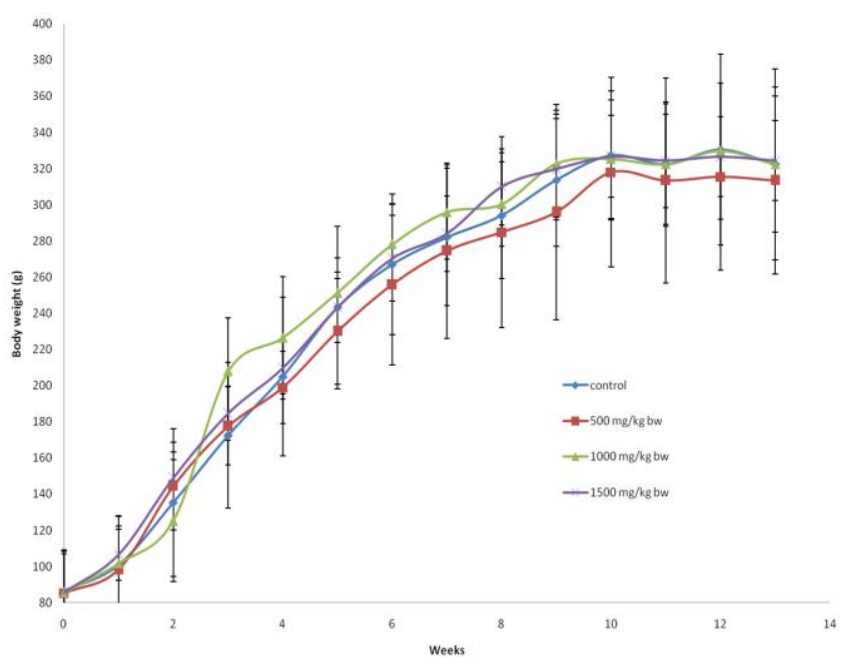

Figure 2. Growth curves of male Sprague Dawley rats administered with KSO-SFE for 90 days

\section{F. Histopathological Studies}

Tissue liver and kidneys were fixed in $\mathrm{RCL}_{2}$. The tissues were processed by the paraffin wax method using Leica automatic tissue processor (TP1020) by dehydrating through ascending grades of alcohol for one hour each in 80\%, 95\%, 95\%, three changes of absolute alcohol, cleared in 3 changes of xylene for one hour each and wax impregnation in 2 changes of paraffin wax for 2 hours each. The tissues were subsequently inserted in paraffin wax employing Leica EG116o embedding machine and sectioned with Leica RT 1120 rotary microtome at $4 \mu \mathrm{m}$ thicknesses. The sections were floated out on water bath at $45^{\circ} \mathrm{C}$ and dried on hot plate at $60^{\circ} \mathrm{C}$ for 30 minutes. The sections were stained with hematoxylin and eosin (H\&E), then examined under light microscope for general tissue structure.

\section{G. Statistical Analysis}

Statistical evaluation was achieved using Statistical Package for Social Science (SPSS) and significant were recognized at $\mathrm{p}<0.05$. Data produced in the study were examined using ANOVA and data were given as mean \pm SD and means were separated using Tukey's multiple comparison test.

\section{RESULT AND DISCUSSION}

The present investigation was carried out to estimate the safety limits of oral administration of KSO-SFE through toxicological assessments in rodents (male Sprague Dawley rats). Kenaf seed is known to yield edible oil and it possesses numerous health benefits, however very little information on its safety and toxicological profile. This investigation provides additional information regarding toxic effect of KSO-SFE on male Sprague Dawley rats.

Safety estimation of medications and green products are commonly performed in animals. It has been demonstrated that there is a close relationship between rats' toxicological effects and human, therefore numerous studies have been done on chronic, subchronic and acute toxicity study of drugs or plant products on rats (Sprague Dawley) (Suh et al., 2020; Zhang et al., 2020; Cladis et al., 2020; de Almeida et al., 2019; Zhu et al., 2019). Subchronic toxicity study (90 days) is designed to assess the probable adverse effects in continuous administration of drugs or plant products over a portion of the regular life spans of laboratory animals such as rats or mice. 
Table 1. Effects of KSO-SFE on organs weight in male Sprague Dawley rats

\begin{tabular}{|c|c|c|c|c|}
\hline Organs & o mg/kg bw & $500 \mathrm{mg} / \mathrm{kg} \mathrm{bw}$ & $1000 \mathrm{mg} / \mathrm{kg} \mathrm{bw}$ & $1500 \mathrm{mg} / \mathrm{kg} \mathrm{bw}$ \\
\hline Brain (g) & $1.82 \pm 0.22^{\mathrm{a}}$ & $1.73 \pm 0.14^{\mathrm{a}}$ & $1.78 \pm 0.12^{\mathrm{a}}$ & $1.74 \pm 0.13^{\mathrm{a}}$ \\
\hline Liver $(\mathrm{g})$ & $7.87 \pm 1.01^{\mathrm{a}}$ & $7.43 \pm 1.5^{2^{\mathrm{a}}}$ & $7.5^{2} \pm 1.08^{a}$ & $7 \cdot 51 \pm 0.98^{a}$ \\
\hline Heart (g) & $1.05 \pm 0.32^{\mathrm{a}}$ & $1.11 \pm 0.18^{\mathrm{a}}$ & $1.09 \pm 0.15^{\mathrm{a}}$ & $1.24 \pm 0.28^{\mathrm{a}}$ \\
\hline Lung (g) & $2.13 \pm 0.99^{a}$ & $1.88 \pm 0.43^{\mathrm{a}}$ & $1.83 \pm 0.17^{\mathrm{a}}$ & $1.79 \pm 0.11^{\mathrm{a}}$ \\
\hline Kidney (g) & $2.34 \pm 0.36^{a}$ & $2.32 \pm 0.38^{a}$ & $2.51 \pm 0.51^{\mathrm{a}}$ & $2.31 \pm 0.21^{\mathrm{a}}$ \\
\hline Small intestine (g) & $5.38 \pm 0.57^{\mathrm{a}}$ & $5.77 \pm 1.42^{\mathrm{a}}$ & $6.01 \pm 1.19^{a}$ & $5.41 \pm 0.67^{\mathrm{a}}$ \\
\hline Testis (g) & $4.11 \pm 0.78^{a}$ & $3.47 \pm 0.66^{\mathrm{a}}$ & $3.73 \pm 0.29^{\mathrm{a}}$ & $3.74 \pm 0.5^{8^{a}}$ \\
\hline Spleen (g) & $0.78 \pm 0.09^{a}$ & $0.82 \pm 0.25^{\mathrm{a}}$ & $0.68 \pm 0.11^{a}$ & $0.84 \pm 0.17^{\mathrm{a}}$ \\
\hline Stomach (g) & $1.76 \pm 0.21^{a}$ & $1.64 \pm 0.32^{\mathrm{a}}$ & $1.68 \pm 0.28^{\mathrm{a}}$ & $1.96 \pm 0.31^{\mathrm{a}}$ \\
\hline Colon (g) & $1.38 \pm 0.15^{\mathrm{a}}$ & $1.54 \pm 0.33^{\mathrm{a}}$ & $1.30 \pm 0.23^{\mathrm{a}}$ & $1.27 \pm 0.05^{\mathrm{a}}$ \\
\hline
\end{tabular}

Data are denoted as mean \pm SD. Data on the same row followed by different superscript letters differ significantly (p $<0.05)$. Body weight (bw).

Table 2. Effects of KSO-SFE on the hematological parameters of male Sprague Dawley rats

\begin{tabular}{|c|c|c|c|c|}
\hline Parameters & o mg/kg bw & $500 \mathrm{mg} / \mathrm{kg} \mathrm{bw}$ & $1000 \mathrm{mg} / \mathrm{kg} \mathrm{bw}$ & $1500 \mathrm{mg} / \mathrm{kg} \mathrm{bw}$ \\
\hline $\mathrm{WBC}\left(10^{3} / \mathrm{uL}\right)$ & $9.10 \pm 2.20^{\mathrm{a}}$ & $12.68 \pm 2.98^{\mathrm{a}}$ & $7.97 \pm 3.98^{\mathrm{a}}$ & $14.00 \pm 5.03^{\mathrm{a}}$ \\
\hline $\mathrm{RBC}\left(10^{6} / \mathrm{uL}\right)$ & $7.08 \pm 0.52^{\mathrm{a}}$ & $8.34 \pm 0.55^{\mathrm{a}}$ & $7.52 \pm 0.81^{\mathrm{a}}$ & $6.39 \pm 1.84^{\mathrm{a}}$ \\
\hline HGB (g/dL) & $12.68 \pm 0.90^{\mathrm{a}}$ & $13.93 \pm 0.92^{\mathrm{a}}$ & $12.70 \pm 1.26^{\mathrm{a}}$ & $11.40 \pm 3.26^{\mathrm{a}}$ \\
\hline HCT (\%) & $38.87 \pm 2.85^{\mathrm{a}}$ & $45.25 \pm 2.54^{\mathrm{a}}$ & $40.17 \pm 4.44^{\mathrm{a}}$ & $34.62 \pm 5 \cdot 31^{\mathrm{a}}$ \\
\hline MCV (fL) & $54.94 \pm 1.25^{\mathrm{a}}$ & $54.35 \pm 1.96^{\mathrm{a}}$ & $53.47 \pm 1.41^{\mathrm{a}}$ & $54.00 \pm 1.09^{\mathrm{a}}$ \\
\hline $\mathrm{MCH}(\mathrm{pg})$ & $17.93 \pm 0.67^{\mathrm{a}}$ & $16.78 \pm 1.5^{6^{a}}$ & $16.93 \pm 0.83^{\mathrm{a}}$ & $17.88 \pm 0.51^{\mathrm{a}}$ \\
\hline $\mathrm{MCHC}(\mathrm{g} / \mathrm{dL})$ & $32.66 \pm 1.39^{a}$ & $30.83 \pm 1.88^{\mathrm{a}}$ & $31.68 \pm 1.20^{\mathrm{a}}$ & $33.08 \pm 0.85^{\mathrm{a}}$ \\
\hline $\operatorname{PLT}\left(10^{3} / \mathrm{uL}\right)$ & $1018.82 \pm 307.65^{a}$ & $865.75 \pm 283.81^{a}$ & $818.83 \pm 376.80^{a}$ & $785.67 \pm 200.96^{a}$ \\
\hline LYM (\%) & $73.30 \pm 7.07^{\mathrm{a}}$ & $76.18 \pm 8.08^{a}$ & $70.50 \pm 5.26^{\mathrm{a}}$ & $80.28 \pm 3.90^{\mathrm{a}}$ \\
\hline LYM\# $\left(10^{3} / \mathrm{uL}\right)$ & $6.62 \pm 1.69^{a}$ & $9.78 \pm 3.09^{\mathrm{a}}$ & $5.73 \pm 2.98^{\mathrm{a}}$ & $11.46 \pm 6.15^{\mathrm{a}}$ \\
\hline RDW (\%) & $14.34 \pm 0.67^{\mathrm{a}}$ & $14.33 \pm 1.00^{\mathrm{a}}$ & $14.90 \pm 1.20^{\mathrm{a}}$ & $13.57 \pm 1.70^{\mathrm{a}}$ \\
\hline PDW (fL) & $8.93 \pm 0.48^{a}$ & $9.40 \pm 1.44^{\mathrm{a}}$ & $9.42 \pm 0.60^{\mathrm{a}}$ & $8.77 \pm 0.67^{a}$ \\
\hline MPV (fL) & $7.44 \pm 0.28^{a}$ & $7.55 \pm 0.79^{\mathrm{a}}$ & $7.52 \pm 0.33^{\mathrm{a}}$ & $7.15 \pm 0.39^{\mathrm{a}}$ \\
\hline P-LCR (\%) & $8.15 \pm 1.76^{\mathrm{a}}$ & $9.10 \pm 4.98^{\mathrm{a}}$ & $8.65 \pm 2.00^{a}$ & $6.58 \pm 1.77^{\mathrm{a}}$ \\
\hline
\end{tabular}

Values are represented as mean \pm SD. Values on the same row followed by different superscript letters differ significantly $(\mathrm{p}<0.05)$. White blood cell (WBC), red blood cell (RBC), hemoglobin (HGB), hematocrit (HCT), mean corpuscular volume (MCV), mean corpuscular hemoglobin (MCH), mean corpuscular hemoglobin concentration (MCHC), platelet (PLT), lymphocyte (LYM), red cell distribution width (RDW), platelet distribution width (PDW), mean platelet volume (MPV), platelet larger cell ratio (P-LCR), body weight (bw). 
Table 3. Effects of KSO-SFE on biochemical parameters of male Sprague Dawley rats

\begin{tabular}{ccccc}
\hline Parameters & $\mathbf{0 ~} \mathbf{~ m g} / \mathbf{k g ~ b w}$ & $\mathbf{5 0 0} \mathbf{~ m g} / \mathbf{k g ~ b w}$ & $\mathbf{1 0 0 0} \mathbf{~ m g} / \mathbf{k g ~ b w}$ & $\mathbf{1 5 0 0 ~} \mathbf{~ m g} / \mathbf{k g ~ b w}$ \\
\hline ALT (U/L) & $103.17 \pm 24.5^{\mathrm{a}}$ & $105.11 \pm 25.44^{\mathrm{a}}$ & $75.47 \pm 20.97^{\mathrm{a}}$ & $86.94 \pm 18.14^{\mathrm{a}}$ \\
Creatinine ( $\mu \mathrm{mol} / \mathrm{L})$ & $81.23 \pm 11.14^{\mathrm{a}}$ & $66.38 \pm 5.35^{\mathrm{b}}$ & $60.67 \pm 11.19^{\mathrm{b}}$ & $64.73 \pm 12.72^{\mathrm{b}}$ \\
Urea (mmol/L) & $8.52 \pm 2.14^{\mathrm{a}}$ & $7.74 \pm 1.94^{\mathrm{a}}$ & $6.35 \pm 1.45^{\mathrm{a}}$ & $6.03 \pm 1.37^{\mathrm{a}}$ \\
Glucose (mmol/L) & $4.10 \pm 2.31^{\mathrm{a}}$ & $5.68 \pm 0.97^{\mathrm{a}}$ & $3.43 \pm 1.44^{\mathrm{a}}$ & $4.84 \pm 2.01^{\mathrm{a}}$ \\
GGT (mmol/L) & $21.40 \pm 4.09^{\mathrm{a}}$ & $22.34 \pm 3.76^{\mathrm{a}}$ & $20.04 \pm 5.98^{\mathrm{a}}$ & $21.67 \pm 3.90^{\mathrm{a}}$ \\
TC (mmol/L) & $0.88 \pm 0.28^{\mathrm{a}}$ & $0.89 \pm 0.16^{\mathrm{a}}$ & $0.62 \pm 0.24^{\mathrm{a}, \mathrm{b}}$ & $0.61 \pm 0.05^{\mathrm{a}, \mathrm{b}}$ \\
TG (mmol/L) & $0.40 \pm 0.20^{\mathrm{a}}$ & $0.52 \pm 0.16^{\mathrm{a}}$ & $0.55 \pm 0.24^{\mathrm{a}}$ & $0.47 \pm 0.07^{\mathrm{a}}$ \\
HDL (mmol/L) & $0.44 \pm 0.14^{\mathrm{a}}$ & $0.48 \pm 0.05^{\mathrm{a}}$ & $0.43 \pm 0.09^{\mathrm{a}}$ & $0.41 \pm 0.13^{\mathrm{a}}$ \\
LDL (mmol/L) & $0.58 \pm 0.19^{\mathrm{a}}$ & $0.54 \pm 0.05^{\mathrm{a}}$ & $0.41 \pm 0.18^{\mathrm{a}}$ & $0.51 \pm 0.06^{\mathrm{a}}$ \\
\hline
\end{tabular}

Data are denoted as mean \pm SD. Data on the same row followed by different superscript letters differs significantly (p< 0.05) compared to control. Body weight (bw), gamma glutamyl transpeptidase (GGT), alanine transaminase (ALT), total cholesterol (TC), triglyceride (TG), high density lipoprotein (HDL), low density lipoprotein (LDL).
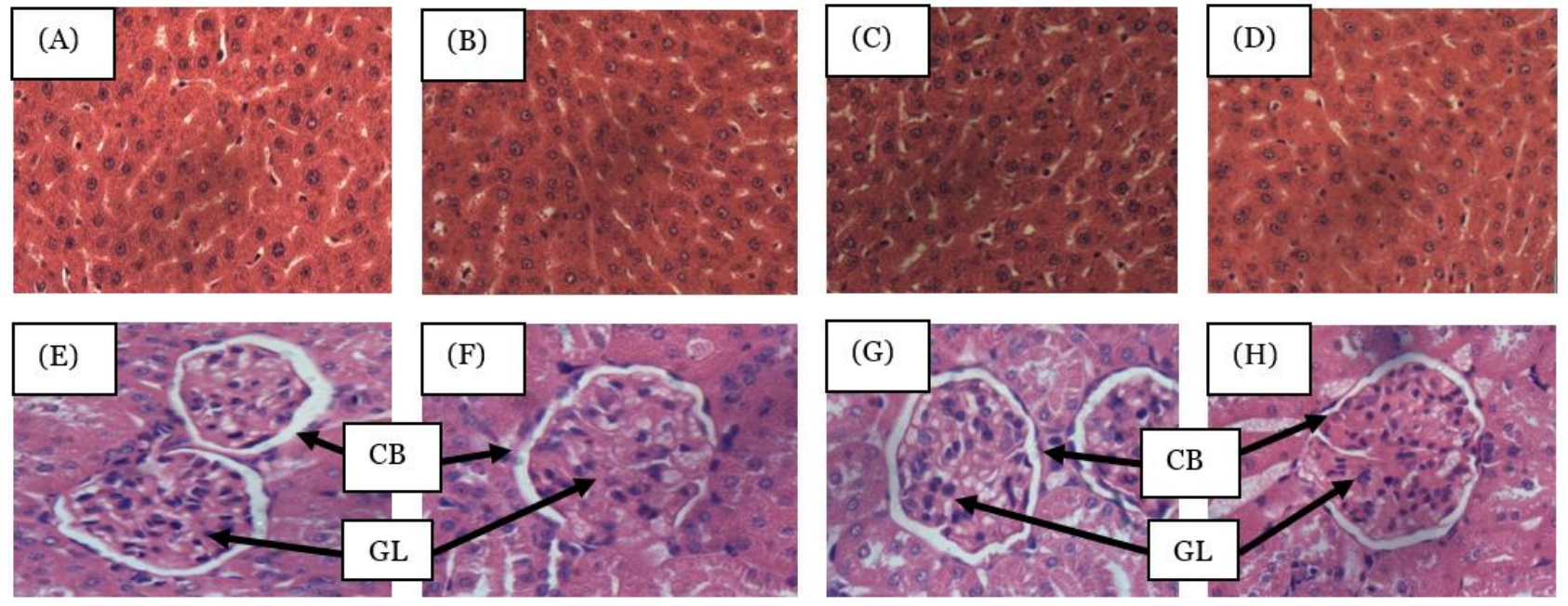

Figure 3. (A), (B), (C), \& (D) showing histological examination of liver hepatocytes and (E), (F), (G) \& (H) showing histological examination of an area of the renal cortex containing several glomeruli (GL) inside the capsule bowman (CB) using H\&E staining. (A) \& (E) o mg/kg bw , (B) \& (F) $500 \mathrm{mg} / \mathrm{kg} \mathrm{bw,} \mathrm{(C)} \mathrm{\&} \mathrm{(G)} 1000 \mathrm{mg} / \mathrm{kg} \mathrm{bw}$, (D) \& (H) $1500 \mathrm{mg} / \mathrm{kg} \mathrm{bw.}$ Body weight (bw)

Unambiguously, they offer valuable evidence regarding the toxicity of these plant products or drugs. It also designed to identify the no observed adverse effect level (NOAEL). NOAEL is described as the maximum dose amount that does not create a significant escalation in adverse outcomes in contrast to the control group (EFSA, 2020). This can deliver the required supporting data to decide appropriate dose treatments for prolonged experiments (Jeon et al., 2020).

The selection of doses was based on study done by Ghafar et al., (2012). The study reported the administration of KSOSFE up to $1500 \mathrm{mg} / \mathrm{kg}$ bw showed chemopreventive activity against colon cancer (Ghafar et al., 2012). Therefore, the present study was designed to administer KSO-SFE at doses
500-1500 mg/kg bw for 90 days. During the administration period, no deaths occurred and there are no notable clinical signs were detected in any of the experimental animals. Changes in body weights throughout the experimental period are revealed in Figure 2. Body weights for all dose groups (500 mg/kg bw, $1000 \mathrm{mg} / \mathrm{kg}$ bw, $1500 \mathrm{mg} / \mathrm{kg} \mathrm{bw}$ ) were comparable to those of the control group. No significant difference ( $p>0.05$ ) were recorded throughout the administration period in the weight of animals. In addition, there is no significant difference in organs weight treated with KSO-SFE at all doses as equated with control group (Table 1). This is a good sign since decrease in body 
weight or changes in organs weight may be an indicator of adverse effect of the treatment received (Zhang et al., 2020).

The results of hematological analysis are summarized in Table 2. All parameters measured (WBC, RBC, HGB, HCT, MCV, MCH, MCHC, PLT, LYM, RDW, PDW, MPV and PLCR) showed no significant difference ( $>>0.05)$ when compared to control group. WBC count shows slightly higher reading in $1500 \mathrm{mg} / \mathrm{kg}$ bw but the difference is statistically irrelevant when compared to control group.

Biochemical analysis (Table 3) revealed that KSO-SFE does not give any effects to ALT, glucose, urea and GGT level except for reducing creatinine level $(\mathrm{p}<0.05)$ when compared to control group. Histopathological study of liver (Figure 3) show no changes or significant structural damage which supports biochemical analysis results for liver enzymes. Despite the lowering effect of creatinine level, it is not toxicological and unlikely to indicate kidney dysfunction. The reading $(60.67 \pm 11.19)$ still falls within normal range (normal range: 35.2-123.2 $\mu \mathrm{mol} / \mathrm{L}$ ) (Suckow et al., 2019). Lower serum creatinine level given it is still within normal range indicates healthy kidneys ( $\mathrm{Hu}$ et al., 2019). Furthermore, there are no changes in kidneys weight and normal structural evidence was observed in histopathological examinations (Figure 3). High creatinine level always related with renal damage/ dysfunction
(Samejima et al., 2019). Whereas for lipid profile (Table 3), there are some reducing effects of TC at dose 1000 and 1500 $\mathrm{mg} / \mathrm{kg}$ bw. This can be explained with the existence of polyunsaturated fatty acids (PUFAs), tocopherols and phytosterol content in KSO-SFE which possessed cholesterol lowering ability (Cheng et al., 2016).

\section{CONCLUSION}

In conclusion, based on the present 90-day subchronic toxicity study, a few changes in biochemical analysis are not toxicological importance since they were within the limit of biological deviation and not associated with histopathological changes. The no observed adverse effect levels (NOAEL) under the condition of this study were parallels to the maximum dose level which is $1500 \mathrm{mg} / \mathrm{kg}$ bw/day. Further investigation on genotoxicity and clinical study should be done to provide more concrete scientific evidence to support KSO-SFE as a safer and healthier oil.

\section{ACKNOWLEDGEMENT}

This investigation was supported out by the financial provision from The Ministry of Plantation Industries and Comodities, Malaysia (Grant no. 54885).

\section{REFERENCES}

Chan, KW \& Ismail, M 2009, 'Supercritical carbon dioxide fluid extraction of Hibiscus cannabinus L. seed oil: a potential solvent-free and high antioxidative edible oil', Food Chemistry, vol. 114, pp. 970-975.

Chew, SC \& Nyam, KL 2019, 'Kenaf (Hibiscus cannabinus L.) seed oil', in Fruit oils: chemistry and functionality, Springer, Cham, pp. 451-494.

Cheng, WY, Akanda, JM \& Nyam, KL 2016, 'Kenaf seed oil: a potential new source of edible oil', Trends in Food Science \& Technology, vol. 52, pp. 57-65.

Cladis, DP, Li, S, Reddavari, L, Cox, A, Ferruzzi, MG \& Weaver, CM 2020, 'A 90 day oral toxicity study of blueberry polyphenols in ovariectomized sprague-dawley rats', Food and Chemical Toxicology, vol. 9, pp. 111254.

de Almeida, TM, von Poser, GL, Müller, LG, Pereira, PR, Cassel E, Vargas RM, da Silva N, Junior N, Driemeier D,
Dallegrave, E \& de Faria Valle, S 2019, 'Oral acute and repeated-doses toxicity study of valepotriates from valeriana glechomifolia (meyer) in mice', Current Drug Discovery Technologies, vol. 16, no.1, pp. 96-103.

European Food Safety Authority (EFSA), Dorne, JL, Manini, P \& Hogstrand, C 2020, 'Animal health risk assessment of multiple chemicals in essential oils for farm animals', EFSA Supporting Publications, vol. 17, no. 1, pp. 176oE.

Ghafar, SAA, Yazan, LS, Tahir, PM \& Ismail, M 2012, 'Kenaf seed supercritical fluid extract reduces aberrant crypt foci formation in azoxymethane-induced rats', Experimental and Toxicologic Pathology, vol. 64, no. 3, pp. 247-51.

Ghafar, SAA, Ismail, M, Yazan, LS, Fakurazi, S, Ismail, N, Chan, KW \& Md Tahir, P 2013, 'Cytotoxic activity of kenaf seed oils from supercritical carbon dioxide fluid extraction towards human colorectal cancer (HT29) cell lines', 
Evidence-Based Complementary and Alternative Nyam, KL, Tan, CP, Lai, OM, Long, K \& Che Man, YB 2009, Medicine, vol. 2013, pp. 1-8.

Giwa Ibrahim, SA, Karim, R, Saari, N, Wan Abdullah, WZ, Zawawi, N, Ab Razak, AF, Hamim, NA \& Umar, RUA 2019, 'Kenaf (Hibiscus cannabinus L.) seed and its potential food applications: a review', Journal of Food Science, vol. 84, no. 8, pp. 2015-2023.

Hu, H, Nakagawa, T, Honda, T, Yamamoto, S, Okazaki, H, Yamamoto, M, Miyamoto, T, Eguchi, M, Kochi, T, Shimizu, M \& Murakami, T 2019, 'Low serum creatinine and risk of diabetes: the Japan epidemiology collaboration on occupational health study', Journal of Diabetes Investigation, vol. 10, no. 5, pp. 1209-1214.

Jeon, WY, Seo, CS, Ha, H, Shin, HK, Cho, JW \& Lee, MY 2020, 'Subchronic toxicological evaluation of Bojungikkitang water extract: 13-week oral repeated-dose toxicity study in Crl: CD (SD) rats', Journal of Ethnopharmacology, vol. 7, pp. 112551.

Khaw, KY, Parat, MO, Shaw, PN \& Falconer, JR 2017, 'Solvent supercritical fluid technologies to extract bioactive compounds from natural sources: a review', Molecules, vol. 22, no. 7, pp. 1186.

Li, P, Sakuragi, K \& Makino, H 2019, 'Extraction techniques in sustainable biofuel production: a concise review', Fuel Processing Technology, vol. 193, pp. 295-303.

Mariod, AA, Matthäus, B \& Ismail, M 2011, 'Comparison of supercritical fluid and hexane extraction methods in extracting kenaf (Hibiscus cannabinus) seed oil lipids', Journal of the American Oil Chemists' Society, vol. 88, no. 7, pp. 931-935.

Masir, N, Ghoddoosi, M, Mansor, S, Abdul - Rahman, F, Florence, CS, Mohamed - Ismail, NA, Tamby, MR \& Md -

Latar, NH 2012, 'RCL2, a potential formalin substitute for tissue fixation in routine pathological specimens', Histopathology, vol. 6o, no. 5, pp. 804-815.

Mohamed, A, Bhardwaj, H, Hamama, A \& Webber, C 1995, 'Chemical composition of kenaf (Hibiscus cannabinus L.) seed oil', Industrial Crops and Products, vol. 4, pp. 157165 .

'Physicochemical properties and bioactive compounds of selected seed oils', LWT - Food Science and Technology, vol. 42, pp. 1396-1403.

OECD 2018, OECD guideline for the testing of chemicals, Test no. 408: repeated dose 90-day oral toxicity study in rodents, <https://www.oecdilibrary.org/environment/test-no-408-repeated-dose-90day-oral-toxicity-study-in-rodents_9789264070707-en, Accessed date: 20 December 2019>.

Samejima, T, Yamashita, T, Takeda, Y \& Adachi, T 2019, 'Low antithrombin levels accompanied by high urine protein/creatinine ratios are predictive of acute kidney injury among CS patients with preeclampsia', The Journal of Maternal-Fetal \& Neonatal Medicine, vol. 12, pp. 1-7.

Suckow, MA, Hankenson, FC, Wilson, RP \& Foley PL 2019, 'The laboratory rat', Academic Press.

Suh, JH, Seo, HW, Han, BC, Kyung, JS \& So, SH 2020, '13week repeated oral dose toxicity study on mixture of Korean red ginseng and deer antler extract in SpragueDawley rats', Toxicological Research, vol. 36, no. 1, pp. 1-2. Yazan, LS, Foo, JB, Ghafar, SAA, Chan, KW, Tahir, PM \& Ismail, M 2011, 'Effect of kenaf seed oil from different ways of extraction towards ovarian cancer cells', Food and Bioproducts Processing, vol. 89, no. 4, pp. 328-32.

Zhang, K, Wang, X, Wang, M, Liu, Y, Zhang, L, Wang, C, Fei, C, Li, J \& Xue, F 2020, 'Rat 90-day oral toxicity study of a novel coccidiostat-Ethanamizuril', Regulatory Toxicology and Pharmacology, vol. 111, pp. 104550.

Zhu, H, Li, R, Zhou, S, Zhang, S, Wang, Y, Liu, S, Song, Q, Chang, X, Zhang, Y, Liu, L \& Tang, L 2019, 'The oral NOAEL of flurochloridone in male Wistar rats in ninetyday subchronic toxicity test was $3 \mathrm{mg} / \mathrm{kg} /$ day', International Journal of Environmental Research and Public Health, vol. 16, no. 4, pp. 553. 